\title{
Soil Urease Activity of Sundarban Mangrove Ecosystem, India
}

\section{Subhajit Das*, Dipnarayan Ganguly, Abhishek Mukherjee, Sabyasachi Chakraborty, Tarun Kumar De}

Department of Marine Science, University of Calcutta, Kolkata, India

Email: *subhajit_310@yahoo.com

How to cite this paper: Das, S., Ganguly, D., Mukherjee, A., Chakraborty, S. and De, T.K. (2017) Soil Urease Activity of Sundarban Mangrove Ecosystem, India. Advances in Microbiology, 7, 617-632.

https://doi.org/10.4236/aim.2017.78048

Received: June 16, 2017

Accepted: August 22, 2017

Published: August 25, 2017

Copyright $\odot 2017$ by authors and Scientific Research Publishing Inc. This work is licensed under the Creative Commons Attribution International License (CC BY 4.0).

http://creativecommons.org/licenses/by/4.0/

\begin{abstract}
Vertical occurrence of soil urease activity along with ammonia content from three distinct regions viz. Deep forest region (No tidal action and wave attack occurs as it is furthest from river shore and it contains maximum content of organic carbon and minimum soil salinity and silicate concentration. In this zone plenty of pneumatophores, below ground root and dense vegetation are found), Rooted region (It is situated in between Deep forest region and Un-rooted region. This region contains only pneumatophores but it is devoid of long roots and vegetations. It faces wave attack and tidal action less than that of Un-rooted region) and Un-rooted region (It is closest to river shore and faces maximum wave attack and tidal action; it contains minimum organic carbon but maximum soil salinity and silicate concentration. This zone is totally devoid of any roots, pneumatophores and vegetations) of Sundarban mangrove forest ecosystem, India revealed an interesting explanation. Soil urease activity showed a decreasing pattern with increase in depth from the deep forest region of the Sundarban forest ecosystem. Soil urease activity was found to be more sensitive to soil temperature and $\mathrm{pH}$ rather than soil salinity. This ensured that soil urease along with the microbes present in the Sundarban forest ecosystem are more tolerant to fluctuation in salinity than that of temperature. Soil ammonia concentration was found to be directly governed by the soil urease activity [The regression equation is Ammonia in soil $=-1.64+0.0402$ Urease Activity $(\mathrm{R}-\mathrm{Sq}=62.9 \%, \mathrm{P}<0.001, \mathrm{n}=41)]$.
\end{abstract}

\section{Keywords}

Soil Urease Activity, Soil Ammonia, Deep Forest Region, Rooted Region, Un-Rooted Region, and Sundarban Forest Ecosystem 


\section{Introduction}

Mangroves accounting for $0.7 \%$ of the tropical forest area are highly productive [1] [2] [3] and afford territory for rich biodiversity [4]. The vast majority of the nutrient pool of mangrove forests is stored in the soil and many mangrove soils have extremely low nutrient availability [5]. Rapid recycling of nutrient from litter is essential to maintain high productivity and microbial processes are more important over chemical processes in the sediment. Nutrient dynamics along with soil enzyme activity of Sundarban mangrove forest is highly influenced by periodic seasonal change, sedimentation rate, water level, leaf fall, etc. In a tropical mangrove forest of Brazil significant sediment accumulation rate was observed to control nutrient status of mangrove sediment [6]. Previous research works reported that mangrove sediments may act as a vast reservoir of organic matter as it initiates the production and rapid burial of the organic matters and it was influenced by sea level rise [7].

Urease (urea amidohydrolase, EC 3.5.1.5) is an important enzyme in soil because of the hydrolytic action on urea that may be excreted in the urine of grazing animals, but its origins, existence and persistence in soil are difficult to understand. The reaction occurs as follows:

$$
\left(\mathrm{NH}_{2}\right)_{2} \mathrm{CO}(\text { Urea })+\mathrm{H}_{2} \mathrm{O} \rightarrow \mathrm{CO}_{2} \uparrow+2 \mathrm{NH}_{3} \uparrow
$$

It is generally believed that a significant proportion of urease activity in soil is released from living and lysed microbial cells and is stabilized as an extra cellular enzyme by association with soil colloids [8], especially soil organic matter [9]. Soil urease activity along with microbial activity was found to be significantly affected by physical disturbance in soil and also by the geochemical parameters [10]. Mangrove ecosystem has unique characteristics to adapt with stressful environments and it has a huge demand for nutrients because of rapid growth of mangrove plants and for fulfillment of such demands the mangrove soil act as a paradise land for several soil enzymes like urease to facilitate easy and quick bio-mineralization processes [11]. Total urease activity in soil may comprise activities associated with viable microorganisms, clay and humic colloids, leaked from extant cells, or released from lysed cells and cell debris. However, urease which becomes associated with humic colloids due to adsorption, entrapment or copolymerization during organic matter formation would persist for a long period [12]. Urease is principally an extra cellular enzyme, representing up to $63 \%$ of total urease activity in soil [13]. Significant occurrence of soil urease activity facilitates biomineralization processes in terms of nitrogen cycle [14]. It is an exclusive venture by the microbial communities, and one of the factors reflected in the activities of this enzyme are the overall size and activity levels of the microbial communities in the soil. Microbial production of urease is also indirectly regulated by the presence of $\mathrm{NH}_{4}^{+}$and/or $\mathrm{NO}_{3}^{-}$ion in the soil sample; their presence will inhibit urease production [15]. However, once in the soil matrix, immobilization or absorption of urease on soil particles and soil organic matter 
has been shown to stabilize its activities [16] [17]. Finer scale variation in urease activity could therefore be the effect of variable concentrations of the enzyme substrate and products, and also the microbial activities in the soil matrix.

Previous study showed that associated rise in soil $\mathrm{pH}$ may increase the soil urease activity and it finally facilitates in hydrolysis of urea which is used as fertilizer in the cultivation field, into $\mathrm{NH}_{3}$ and $\mathrm{CO}_{2}$ [18] [19]. Ammonia produced by the action of soil urease activity may escape from the soil because of volatile nature of ammonia [20] [21]. Due to this participation of soil urease regarding Nitrogen mineralization, urease activities in soils have established a lot of concentration because it was first explained by Rotini (1935) [22], an essential process in the regulation of Nitrogen supply to plants after fertilizing with urea. Polacco reported in 1977 [23] that plants mainly secrete soil urease and previous study reported that microorganisms may also secrete urease as both intra-cellular and extra-cellular enzymes [24] [25]. Surprisingly, after secretion from plants or microorganisms, urease being protein in nature can easily be degraded by soil by proteolytic enzymes [12] [26]. This may imply that a considerable fraction of ureolytic activity in the soil may be carried out by extracellular urease, which thus can be stabilized by immobilization on organic and mineral soil colloids. Urease activity in soils can be influenced by many physico-chemical parameters viz. cropping history, organic matter content of the soil, soil depth, soil amendments, concentration of heavy metals, temperatures etc. [27] [28]. Generally, urease activity increases with increasing temperature until a critical temperature is reached when denaturation of the protein present in urease enzyme is initiated and the reaction rate begins to decrease [29]. It is suggested that higher temperatures increase the activity coefficient of this enzyme. The present study explored seasonal, spatial and vertical abundance of soil urease activity along with ammonia content and their correlative interaction relating to Nitrogen mineralization and probable influences of soil parameters on soil urease activity. The hypothesis of the study depicted that impact of soil temperature on urease activity would play a more crucial role than soil salinity in relation to Nitrogen cycle in the Sundarban Mangrove Forest, India.

\section{Methods and Materials}

\subsection{Study Area}

The Sundarban Mangrove forest is located geographically in between $21^{\circ} 31^{\prime} \mathrm{N}$ and $22^{\circ} 30^{\prime} \mathrm{N}$ and longitude $88^{\circ} 10^{\prime} \mathrm{E}$ and $89^{\circ} 51^{\prime} \mathrm{E}$ along the North East coast of Bay of Bengal, India. This mangrove forest is a part of the estuarine system of the River Ganges, NE coast of Bay of Bengal (Figure 1), which covers $9630 \mathrm{~km}^{2}$. Several numbers of discrete islands constitute Sundarban. The climate in the region is characterized by the southwest monsoon (June-September), northeast monsoon or post-monsoon (October-January), and pre-monsoon (February-May) with $70 \%-80 \%$ of annual rainfall occurs during the summer monsoon 


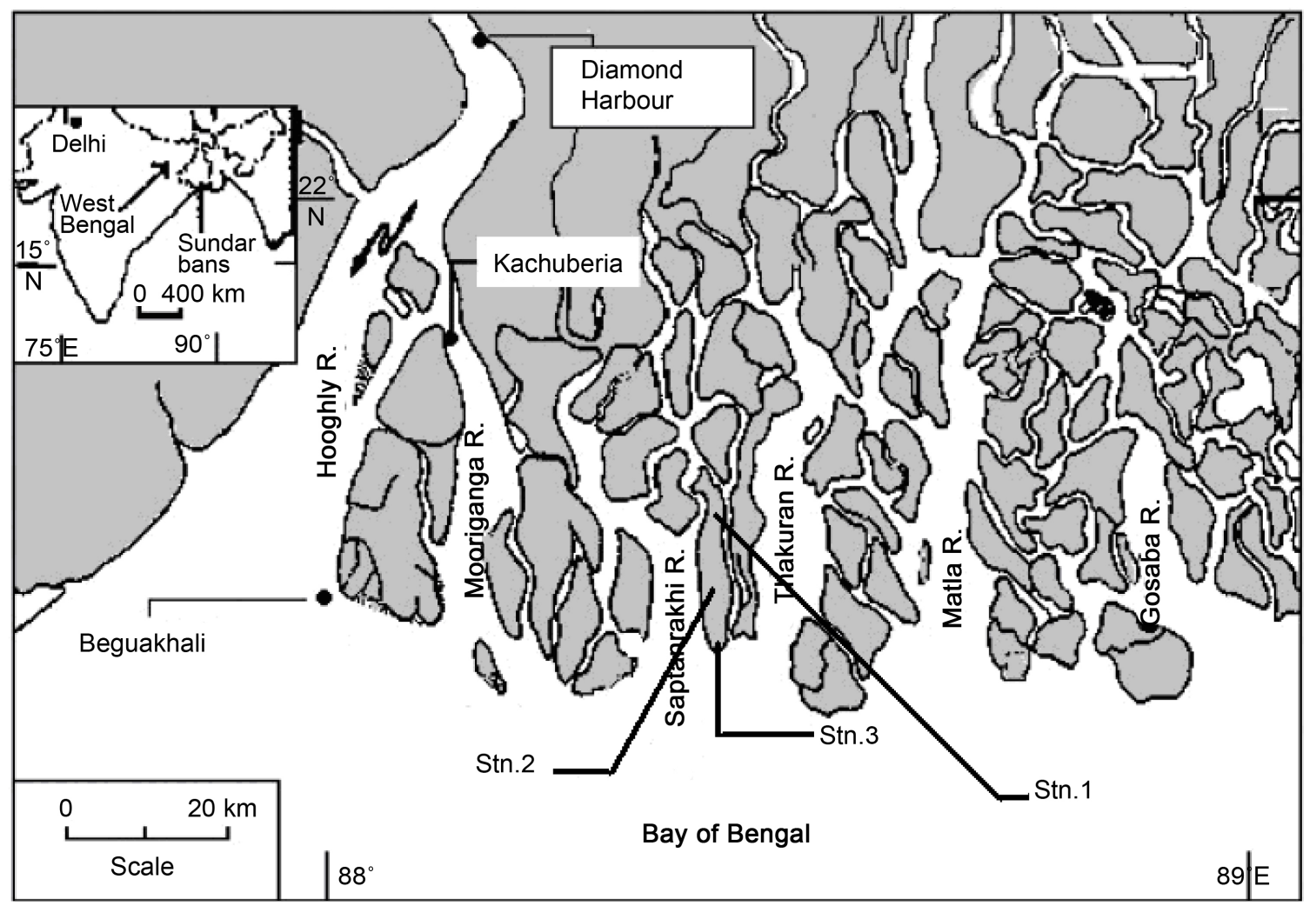

Figure 1. Map showing the study area.

(southwest monsoon). The tide in this estuarine complex is semidiurnal in nature with spring tide ranging between $4.27 \mathrm{~m}$ and $4.75 \mathrm{~m}$ and neap tide range between $1.83 \mathrm{~m}$ and $2.83 \mathrm{~m}$. It is a unique bioclimatic zone in between the land and ocean boundaries of the Bay of Bengal and the largest delta on the globe. The deltaic terrain of Sundarban Biosphere Reserve comprises mainly saline alluvial soil consisting of clay, silt, fine and coarse sand particles.

\subsection{Description of the Three Sampling Stations}

Sediment cores were collected from three distinct zones namely Deep forest region [in which no tidal action and wave attack occurs as it is furthest from river shore and it contains maximum content of organic carbon and minimum soil salinity and silicate concentration. In this zone plenty of pneumatophores, below ground root and dense vegetation are found (Station 1)], Rooted region [which is situated in between Deep forest region and Un-rooted region. This region contains only pneumatophores but it is devoid of long roots and vegetations. It faces wave attack and tidal action less than that of Un-rooted region (Station 2)], \& Un-rooted regions [which is closest to river shore and faces maximum wave attack and tidal action; it contains minimum organic carbon but maximum soil salinity and silicate concentration. This zone is totally devoid of any roots, pneumatophores and vegetations (Station 3)] of Sundarban mangrove ecosystem in every month from six different depths i.e. 1) $0-10 \mathrm{~cm}, 2) 10-20 \mathrm{~cm}, 3) 20-$ 
$30 \mathrm{~cm}$, 4) $30-40 \mathrm{~cm}, 5) 40-50 \mathrm{~cm}$, \& 6) $50-60 \mathrm{~cm}$, aseptically using a hand-held stainless steel core sampler $(3.2 \mathrm{~cm}$ diameter, $100 \mathrm{~cm}$ long). Samples were collected into sterilized containers and immediately transferred to the laboratory for analyses.

\subsection{Determination of Soil Parameters}

\subsubsection{Extraction of Soil Samples}

Soil sub samples of $30 \mathrm{~g}$ were weighed and transferred to $100 \mathrm{ml}$ stopper conical flask and was shaken with exactly $75 \mathrm{ml}$ of $2 \mathrm{~mol} \cdot \mathrm{L}^{-1}$ potassium chloride ( $\left.\mathrm{KCl}\right)$. The mixture was shaken until well mixed and allowed to stand overnight. The samples were filtered into Buchner funnels by using filter papers Whatman no. 42. In the case of turbid filtrates, they were centrifuged by using $3000 \mathrm{cycle} / \mathrm{min}$ centrifuge for $5 \mathrm{~min}$. Finally desired volume of the supernatant was collected for the estimation of concentration of ammonia.

\subsubsection{Determination of Ammonia in Soil [Phenol-Hypochlorite Method (Grasshoff, 1983)]}

Accurately $50 \mathrm{ml}$ of suitably diluted (dilution was done by distilled water) soil extracted solution was taken and concentration of ammonia was determined following standard method [30].

\subsubsection{Organic Carbon in Soil Sample: (Walkey and Black, 1934)}

Organic carbon in sediment was measured by Walkey-Black method. $10 \mathrm{ml} 1 \mathrm{~N}$ potassium dichromate $\left(\mathrm{K}_{2} \mathrm{Cr}_{2} \mathrm{O}_{7}\right)$ and $20 \mathrm{ml}$ conc. sulphuric acid solution mixed with silver sulphate $\left(1.25 \mathrm{~g} \mathrm{Ag}_{2} \mathrm{SO}_{4}\right.$ with $\left.100 \mathrm{ml} \mathrm{H}_{2} \mathrm{SO}_{4}\right)$ were added with $1 \mathrm{~g}$ dried sediment sample. After allowing it to stand for $30 \mathrm{~min}$ mixture was diluted with $200 \mathrm{ml}$ distilled water followed by the addition of $85 \%$ conc. phosphoric acid $\left(\mathrm{H}_{3} \mathrm{PO}_{3}\right)$ and $1 \mathrm{ml}$ of diphenyl amine $(0.5 \mathrm{~g}$ diphenyl amine in the mixture of 100 $\mathrm{ml}$ of conc. $\mathrm{H}_{2} \mathrm{SO}_{4}$ and $20 \mathrm{ml}$ distilled water) indicator. Mixture was titrated with Mohr salt (393.13 g Mohr salt was dissolved in distilled water, in presence of 50 $\mathrm{ml}$ conc. sulphuric acid and the volume was made upto $1 \mathrm{~L}$ ) until the blue colour was changed to brilliant green. Same procedure was followed for blank without using sediment [31].

\subsubsection{Measurement of Soil Temperature, $\mathrm{Ph}$ and Eh Value}

The $\mathrm{pH}$ value was measured in a 1:5 (w/w) soil water suspension using an electric digital $\mathrm{pH}$ meter [31] and salinity of a soil saturation extract (ECe) was determined by measuring the electrical conductance of soil extract with the help of a conductivity meter [32]. Soil temperature was measured at different depths using thermocouple probes $\left( \pm 0.1^{\circ} \mathrm{C}\right.$ accuracy). Soil redox potential value $(\mathrm{Eh})$ at each sampling depth from three distinct sampling zones was with brightened platinum electrodes which were allowed to equilibrate in situ for $1 \mathrm{hr}$ prior to measurement. Each electrode was checked before use with quinhydrone in $\mathrm{pH} 4$ and 7 buffers ( $\mathrm{mV}$ reading for quinhydrone is 218 and 40.8, respectively, at $\left.25^{\circ} \mathrm{C}\right)$. The potential of a calomel reference electrode $(+244 \mathrm{mV})$ was added to 
each value to calculate Eh. Eh values were not corrected for $\mathrm{pH}$, since differences between paired sites were negligible (mean $\mathrm{pH}=6.73 \pm 0.05$ for all sites). A correction for temperature was also not calculated since Eh values change less than $1 \mathrm{mV}$ for every ${ }^{\circ} \mathrm{C}[33][34]$.

\subsubsection{Determination of Soil Urease Activity}

Moist soil sample of $1.5 \mathrm{~g}$ from different sapling zone was incubated with $0.5 \mathrm{ml}$ of $79.9 \mathrm{mM}$ urea (substrate) solution for $2 \mathrm{hr}$ at in situ temperature. The released $\mathrm{NH}_{4}^{+}$from urea by the soil urease was determined spectrophotometrically at $660 \mathrm{~nm}$ after treatment of the incubated soil sample with $\mathrm{KCl}$ and $\mathrm{HCl}$. The activity of soil urease has been expressed as $\mu \mathrm{g} \mathrm{NH}_{4}^{+}-\mathrm{N} \mathrm{g}^{-1}$ dry wt of soil [35] .

\subsubsection{Statistical Analysis}

All the statistical analyses were done using a MINITAB (version 13.0) statistical package.

\section{Result and Discussion}

A depth wise seasonal study was done for soil urease enzyme activity along with ammonia content from 1) Deep forest region, 2) Rooted region and 3) Un-rooted region.

\subsection{Deep Forest Region}

Maximum soil urease activity $\left(178.67 \mu \mathrm{g} \mathrm{NH}_{4}^{+}-\mathrm{N}\right.$ produced $\mathrm{g}^{-1}$ dry wt of soil) was found from the surface soil of Deep forest region during Post monsoon and minimum urease activity $\left(69.25 \mu \mathrm{g} \mathrm{NH}_{4}^{+}-\mathrm{N}\right.$ produced $\mathrm{g}^{-1}$ dry wt of soil) was found from the $60 \mathrm{~cm}$ of depth during monsoon. In three seasons soil urease activity decreased with increase in depth in the Deep forest region. Previous research study reported that urease activity might decrease with increase in depth [26] [36]. A reverse profile for ammonia content of soil was found (Figures 2(a)-(c)). Maximum ammonia (6.19 $\mu \mathrm{g} \mathrm{NH}_{4}^{+}-\mathrm{N} \mathrm{g}^{-1}$ dry wt of soil) content was found from the soil of $60 \mathrm{~cm}$ of depth during post monsoon whereas minimum value (1.43 $\mu \mathrm{g} \quad \mathrm{NH}_{4}^{+}-\mathrm{N} \mathrm{g}^{-1}$ dry wt of soil) was found from the surface soil during monsoon. It may be predicted that decreasing organic carbon with increase in depth causes lowering of microbial load which ultimately reflects on lowering of soil urease activity with increasing depth [25]. More anoxic condition in the deeper soil may inhibit the oxidation of ammonia for which in the Deep forest region the content of ammonia in soil was found to increase with increasing depth [37].

A negative correlation was found for the content of ammonia in soil and soil urease activity [The regression equation is ammonia in soil $=-1.64+0.0402$ Urease Activity ( $\mathrm{R}-\mathrm{Sq}=62.9 \%, \mathrm{P}<0.001, \mathrm{n}=41)]$. A decreasing pattern of salinity, organic carbon and temperature was found with increase in depth. Maximum of soil organic Carbon (1.37\%) was found during post monsoon from the surface soil and minimum organic Carbon (0.59\%) was found during monsoon 


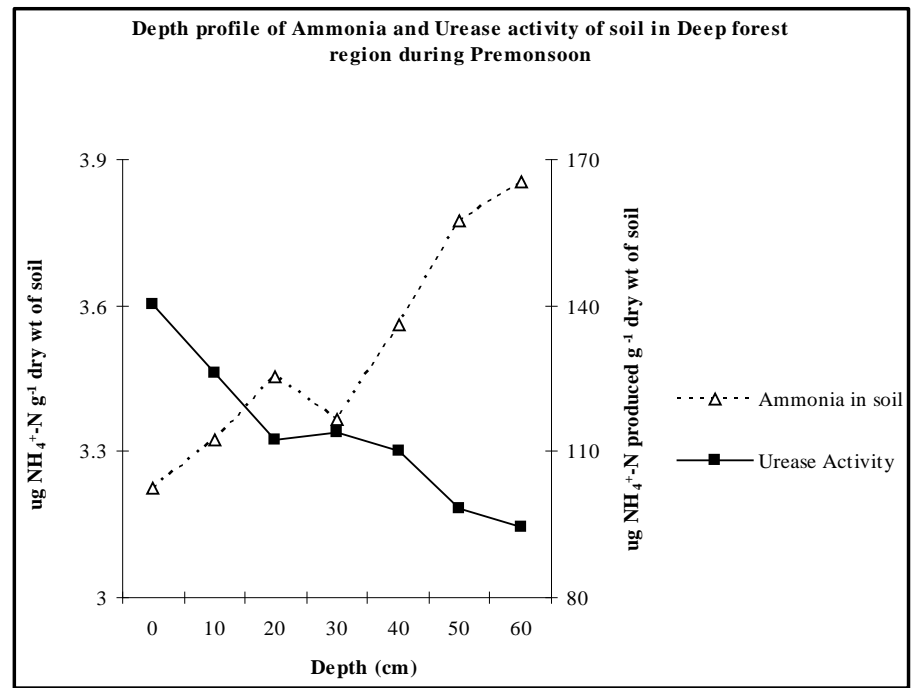

(a)

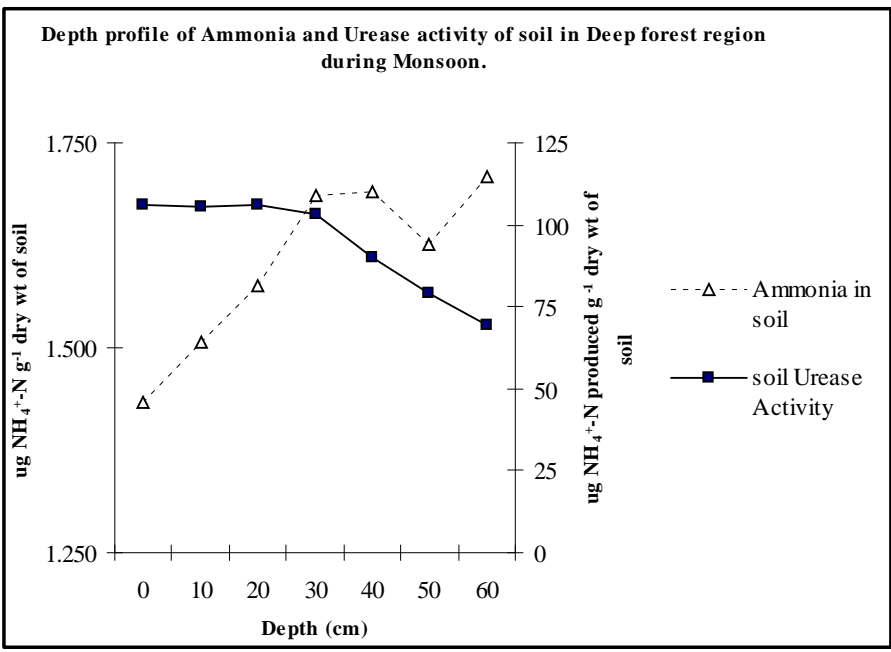

(b)

Depth profile of Ammonia and Urease activity of soil in Deep forest region during Post monsoon.

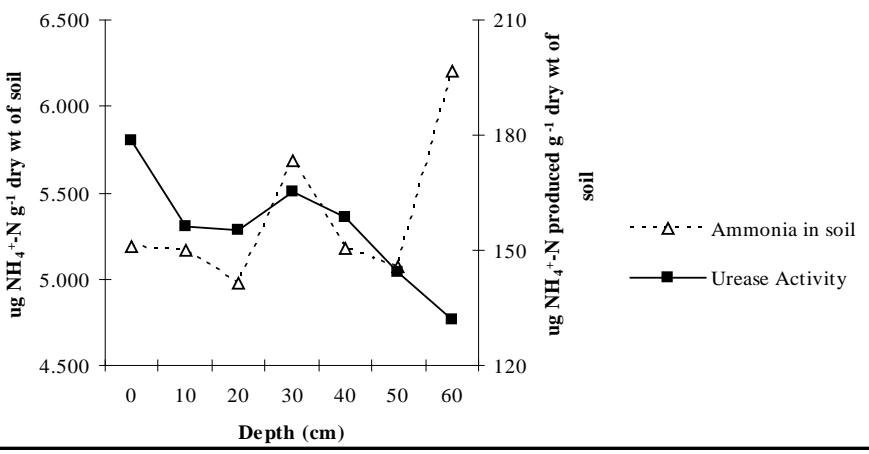

(c)

Figure 2. Depth profile of the content of Ammonia in soil and soil Urease activity in the Deep forest region during Premonsoon (a), Monsoon (b) and Post monsoon (c). 
season from the soil of $60 \mathrm{~cm}$ of depth [38]. The distinct stratification of soil urease, ammonia content, organic Carbon was found in the deep forest region which may be attributed to more vertical stability of the soil in that region [39]. Maximum salinity (20.06 psu) was found from the $60 \mathrm{~cm}$ of depth during postmonsoon and minimum (15.37 psu) was found during monsoon season from the surface soil. Maximum soil temperature $\left(24.70^{\circ} \mathrm{C}\right)$ was found during monsoon from the $10 \mathrm{~cm}$ of depth whereas minimum soil temperature $\left(12.93^{\circ} \mathrm{C}\right)$ was found during post-monsoon from the $30 \mathrm{~cm}$ of depth. Maximum of soil $\mathrm{pH}$ (8.42) was found during post-monsoon from the surface soil and minimum $\mathrm{pH}$ (7.94) was found during pre-monsoon from the surface soil of deep forest region (Table 1).

\subsection{Rooted Region}

In rooted region similar pattern of vertical distribution of ammonia content and soil urease activity was found in three seasons. Maximum soil urease activity (156.24 $\mu \mathrm{g} \mathrm{NH}_{4}^{+}-\mathrm{N}$ produced $\mathrm{g}^{-1}$ dry wt of soil) was found from the surface soil

Table 1. Seasonal and vertical fluctuation of $\mathrm{pH}$, temp, Salinity and organic carbon in the soil of deep forest region.

\begin{tabular}{|c|c|c|c|c|c|}
\hline Season & $\begin{array}{l}\text { Depth } \\
(\mathrm{cm})\end{array}$ & Avg. pH & $\begin{array}{c}\text { Avg. } \\
\text { Temp }\left({ }^{\circ} \mathrm{C}\right)\end{array}$ & $\begin{array}{l}\text { Avg. Salinity } \\
\text { (PSU) }\end{array}$ & Org.C (\%) \\
\hline \multirow{7}{*}{ Premonsoon } & 0 & 7.94 & 17.83 & 15.62 & 1.03 \\
\hline & 10 & 8.394 & 17.83 & 15.95 & 0.97 \\
\hline & 20 & 8.273 & 17.82 & 16.15 & 0.92 \\
\hline & 30 & 8.23 & 17.81 & 16.12 & 0.82 \\
\hline & 40 & 8.251 & 17.82 & 16.32 & 0.78 \\
\hline & 50 & 8.214 & 17.8 & 16.5 & 0.75 \\
\hline & 60 & 8.194 & 17.82 & 16.85 & 0.7 \\
\hline \multirow{7}{*}{ Monsoon } & 0 & 8.218 & 24.68 & 15.37 & 0.87 \\
\hline & 10 & 8.17 & 24.7 & 15.7 & 0.82 \\
\hline & 20 & 8.185 & 25.17 & 15.85 & 0.8 \\
\hline & 30 & 8.18 & 24.69 & 15.92 & 0.83 \\
\hline & 40 & 8.136 & 24.59 & 16 & 0.7 \\
\hline & 50 & 8.156 & 23.82 & 16.05 & 0.67 \\
\hline & 60 & 8.119 & 23.73 & 16.37 & 0.59 \\
\hline \multirow{7}{*}{ Post monsoon } & 0 & 8.423 & 12.943 & 18.76 & 1.37 \\
\hline & 10 & 8.365 & 12.945 & 19.29 & 1.26 \\
\hline & 20 & 8.338 & 12.938 & 19.32 & 1.25 \\
\hline & 30 & 8.32 & 12.93 & 19.39 & 1.07 \\
\hline & 40 & 8.24 & 12.9 & 19.68 & 0.97 \\
\hline & 50 & 8.24 & 12.923 & 19.93 & 0.92 \\
\hline & 60 & 8.185 & 13.123 & 20.06 & 0.93 \\
\hline
\end{tabular}


of rooted region during Post monsoon and minimum urease activity $(49.45 \mu \mathrm{g}$ $\mathrm{NH}_{4}^{+}-\mathrm{N}$ produced $\mathrm{g}^{-1}$ dry wt of soil) was found from the $60 \mathrm{~cm}$ of depth during monsoon. Ammonia content in soil was found to increase with increase in depth which is just mirror image or vertical distribution of soil urease activity. Maximum ammonia (4.87 $\mu \mathrm{g} \mathrm{NH}_{4}^{+}-\mathrm{N} \mathrm{g}^{-1}$ dry wt of soil) content was found from the soil of $60 \mathrm{~cm}$ of depth during post monsoon whereas minimum value $(0.98 \mu \mathrm{g}$ $\mathrm{NH}_{4}^{+}-\mathrm{N} \mathrm{g}^{-1}$ dry wt of soil) was found from the soil of $20 \mathrm{~cm}$ of depth during monsoon (Figures $3(\mathrm{a})$-(c)). In rooted region maximum of soil organic Carbon $(1.13 \%)$ was found from the surface soil during post-monsoon and minimum organic Carbon (0.52\%) was found during pre-monsoon from the $60 \mathrm{~cm}$ of depth. Maximum salinity (20.79 psu) was found from the $50 \mathrm{~cm}$ of depth during post-monsoon and minimum (15.63 psu) was found during monsoon season from the surface soil. Maximum soil temperature $\left(25.27^{\circ} \mathrm{C}\right)$ was found during monsoon from the $20 \mathrm{~cm}$ of depth whereas minimum soil temperature $\left(12.71^{\circ} \mathrm{C}\right)$ was found during post-monsoon from the $50 \mathrm{~cm}$ of depth. Maximum of soil $\mathrm{pH}$ (8.29) was found during post-monsoon from the surface soil and minimum $\mathrm{pH}$ (7.98) was found during monsoon from the $40 \mathrm{~cm}$ of depth (Table 2).

\subsection{Un-Rooted Region}

In Un-rooted region no distinct vertical stratification was found for both ammonia content in soil and soil urease activity. Maximum soil urease activity (126.45 $\mu \mathrm{g} \mathrm{NH}_{4}^{+}-\mathrm{N}$ produced $\mathrm{g}^{-1}$ dry wt of soil) was found from the soil of 50 $\mathrm{cm}$ of depth during Post monsoon and minimum urease activity $\left(55.33 \mu \mathrm{g} \mathrm{NH}_{4}^{+}-\mathrm{N}\right.$ produced $\mathrm{g}^{-1}$ dry wt of soil) was found from the $60 \mathrm{~cm}$ of depth during Premonsoon. Maximum ammonia (3.35 $\mu \mathrm{g} \mathrm{NH}_{4}^{+}-\mathrm{N} \mathrm{g}^{-1}$ dry wt of soil) content was found from the soil of $40 \mathrm{~cm}$ of depth during post monsoon whereas minimum value $\left(0.63 \mu \mathrm{g} \mathrm{NH}_{4}^{+}-\mathrm{N} \mathrm{g}^{-1}\right.$ dry wt of soil) was found from the surface soil during monsoon (Figures $4(\mathrm{a})-(\mathrm{c})$ ). In un-rooted region maximum of soil organic Carbon $(1.00 \%)$ was found from the surface soil during post-monsoon and minimum organic Carbon (0.42\%) was found during monsoon from the $20 \mathrm{~cm}$ of depth. Maximum salinity (21.58 psu) was found from the $60 \mathrm{~cm}$ of depth during post-monsoon and minimum (16 psu) was found during monsoon season from the $20 \mathrm{~cm}$ of depth. Maximum soil temperature $\left(25.22^{\circ} \mathrm{C}\right)$ was found during monsoon from the surface soil whereas minimum soil temperature $\left(12.88^{\circ} \mathrm{C}\right)$ was found during post-monsoon from the $50 \mathrm{~cm}$ of depth. Maximum of soil $\mathrm{pH}$ (8.33) was found during post-monsoon from the $40 \mathrm{~cm}$ of depth and minimum $\mathrm{pH}$ (7.64) was found during monsoon from the $60 \mathrm{~cm}$ of depth (Table 3). No distinct stratification of soil urease, ammonia content, organic Carbon was found in the un-rooted region which may be attributed to less vertical stability of the soil in that region due to extreme wave attack [40].

Stepwise regression analysis of data (Table 4) showed that soil urease activity could explain only $0.1 \%$ of the variation of soil salinity compared to $52.6 \%, 9.3 \%$, $12.8 \%$ and $1.9 \%$ by $\mathrm{pH}, \mathrm{T}$ (Temperature in ${ }^{\circ} \mathrm{C}$ ), Org.C (\%) and soil ammonia 


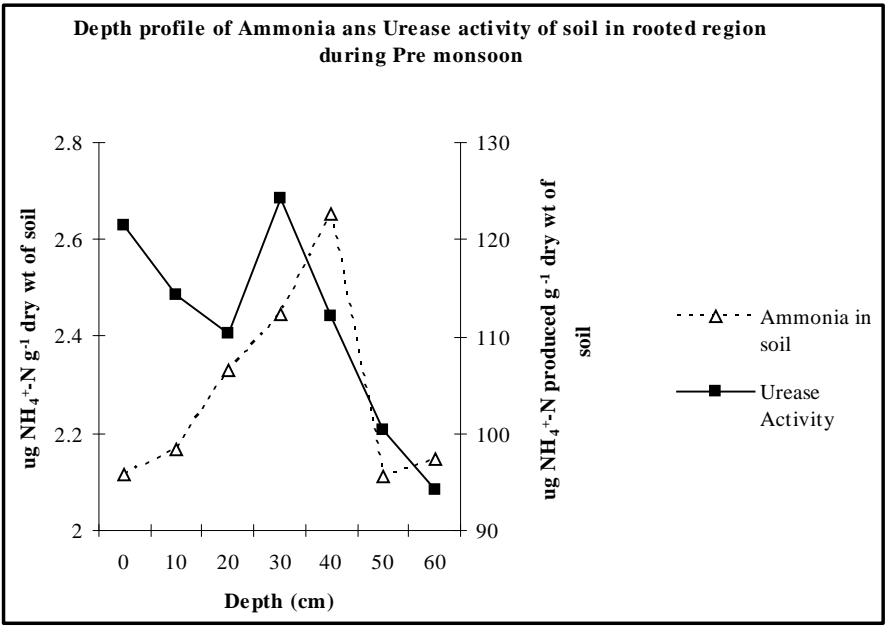

(a)

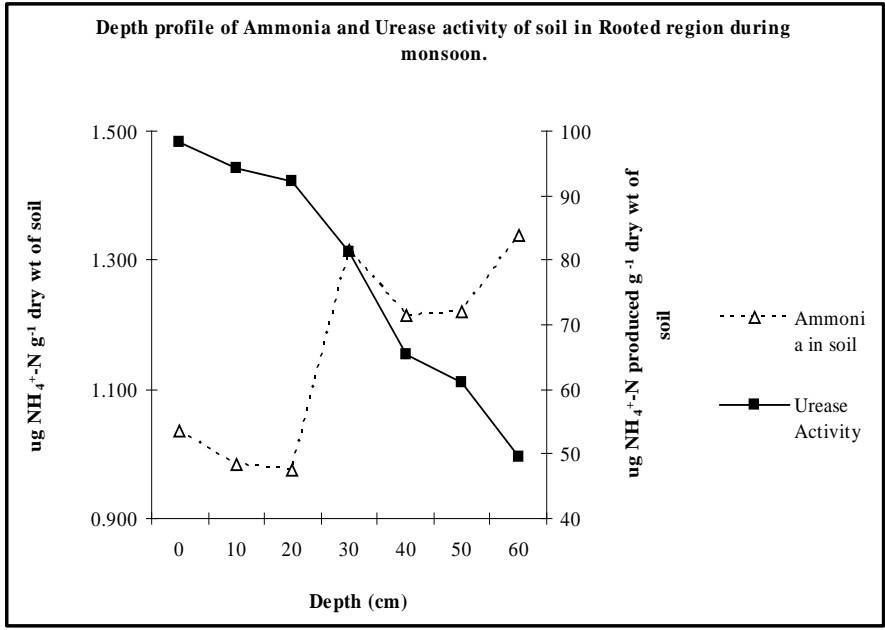

(b)

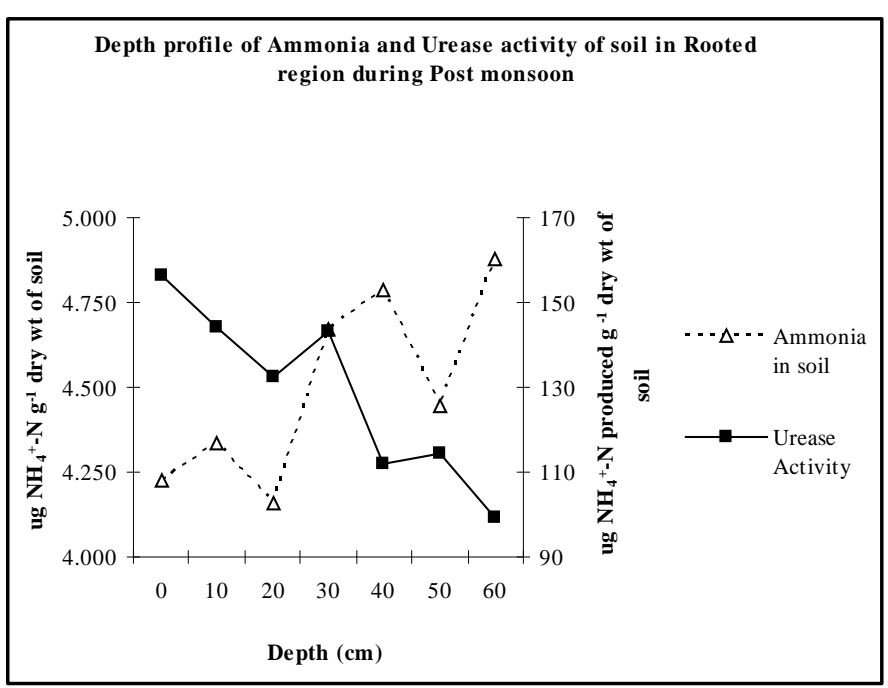

(c)

Figure 3. Depth profile of the content of Ammonia in soil and soil Urease activity in the Rooted region during Premonsoon (a), Monsoon (b) and Post monsoon (c). 


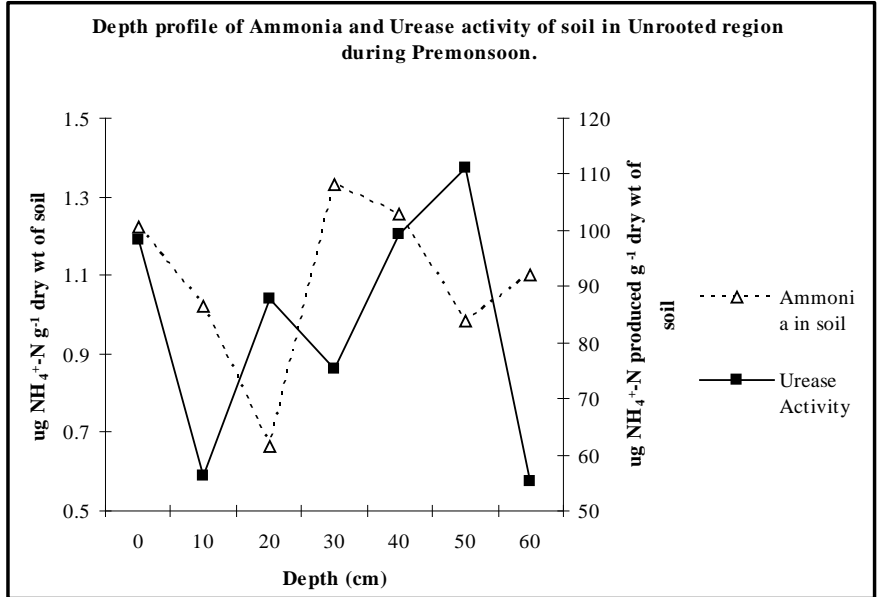

(a)

Depth profile of Ammonia and Urease activity of soil in Unrooted region during Monsoon

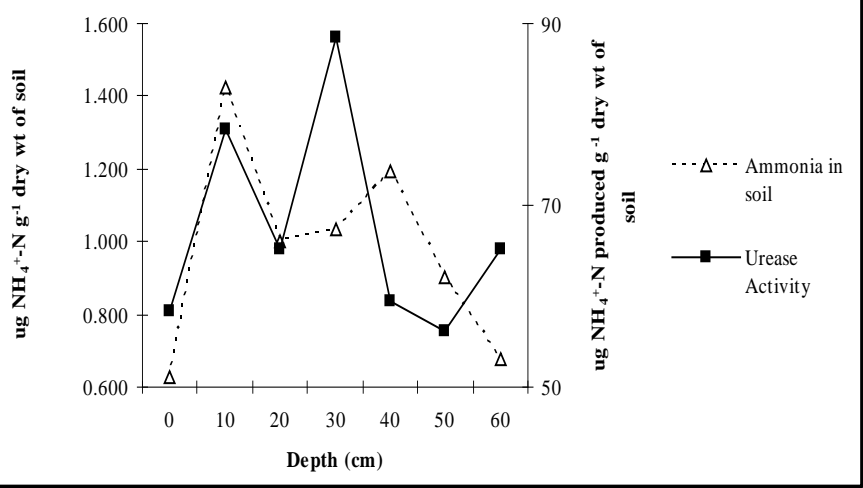

(b)

Depth profile of Ammonia and Urease activity of soil in Unrooted region during Post monsoon

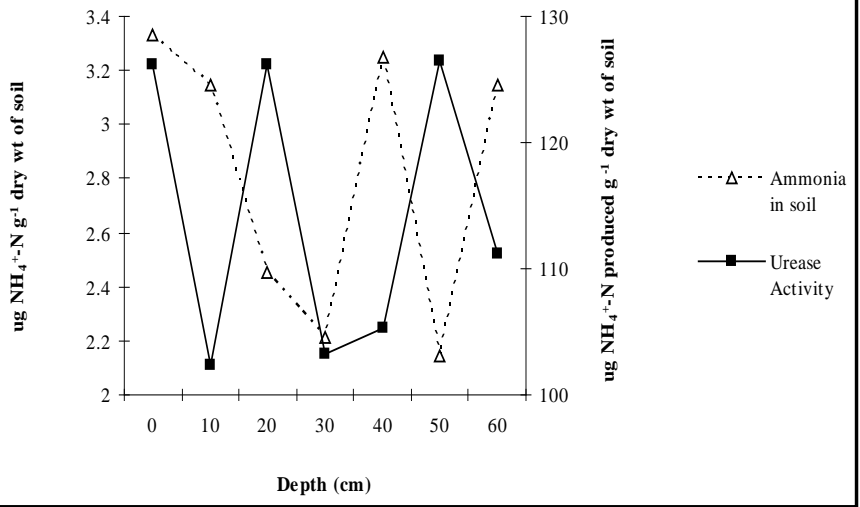

(c)

Figure 4. Depth profile of the content of Ammonia in soil and soil Urease activity in the Unrooted region during Premonsoon (a), Monsoon (b) and Post monsoon (c). 
Table 2. Seasonal and vertical fluctuation of $\mathrm{pH}$, temp, salinity and organic carbon in the soil of rooted region.

\begin{tabular}{|c|c|c|c|c|c|}
\hline Season & Depth $(\mathrm{cm})$ & Avg. pH & Avg. Temp $\left({ }^{\circ} \mathrm{C}\right)$ & Avg. Salinity (PSU) & Org.C (\%) \\
\hline \multirow{7}{*}{ Pre monsoon } & 0 & 8.207 & 18.27 & 16.875 & 0.64 \\
\hline & 10 & 8.193 & 18.26 & 16.85 & 0.56 \\
\hline & 20 & 8.164 & 18.25 & 16.775 & 0.6 \\
\hline & 30 & 8.219 & 18.25 & 16.74 & 0.63 \\
\hline & 40 & 8.196 & 18.24 & 17.275 & 0.52 \\
\hline & 50 & 8.006 & 18.24 & 17.55 & 0.53 \\
\hline & 60 & 8.118 & 18.23 & 17.2 & 0.52 \\
\hline \multirow{7}{*}{ Monsoon } & 0 & 8.119 & 24.71 & 15.63 & 0.83 \\
\hline & 10 & 8.025 & 24.73 & 15.9 & 0.77 \\
\hline & 20 & 8.092 & 25.27 & 16.15 & 0.71 \\
\hline & 30 & 8.01 & 24.81 & 15.87 & 0.72 \\
\hline & 40 & 7.986 & 24.75 & 16.22 & 0.64 \\
\hline & 50 & 8.026 & 23.93 & 16.45 & 0.63 \\
\hline & 60 & 8.024 & 23.89 & 16.87 & 0.58 \\
\hline \multirow{7}{*}{ Post monsoon } & 0 & 8.29 & 12.73 & 20.13 & 1.13 \\
\hline & 10 & 8.25 & 12.72 & 20.34 & 0.94 \\
\hline & 20 & 8.25 & 12.71 & 20.03 & 0.93 \\
\hline & 30 & 8.23 & 12.71 & 19.76 & 0.79 \\
\hline & 40 & 8.15 & 12.7 & 20.46 & 0.79 \\
\hline & 50 & 8.158 & 12.7 & 20.79 & 0.83 \\
\hline & 60 & 8.165 & 12.9 & 20.72 & 0.86 \\
\hline
\end{tabular}

content ( $\mu \mathrm{g} \mathrm{NH}_{4}^{+}-\mathrm{N}$ produced $\mathrm{g}^{-1}$ dry wt of soil) respectively. Previous study showed that soil temperature had significant control over soil urease activity [41]. This result signified that change in soil salinity of the Sundarban mangrove ecosystem did not affect the microbial activity, compared to soil temperature and $\mathrm{pH}$, relating to soil urease activity, which intern assigns the salt tolerance ability of the soil urease activity of that ecosystem.

\section{Conclusion}

The present study revealed that Deep forest region contained more ammonia, organic carbon, soil urease activity than Rooted and Un-rooted region. Soil urease activity was sensitive to soil temperature ant soil $\mathrm{pH}$ value, whereas salinity did not affect too much on urease activity due to salt tolerance ability. Soil urease activity decreased with increase in depth mainly in undisturbed Deep forest 
Table 3. Seasonal and vertical fluctuation of $\mathrm{pH}$, temp, salinity and organic carbon in the soil of unrooted region.

\begin{tabular}{|c|c|c|c|c|c|}
\hline Season & Depth $(\mathrm{cm})$ & Avg. $\mathrm{pH}$ & Avg. Temp $\left({ }^{\circ} \mathrm{C}\right)$ & Avg. Salinity (PSU) & Org.C (\%) \\
\hline \multirow{7}{*}{ Pre monsoon } & 0 & 8.169 & 18.41 & 17.13 & 0.55 \\
\hline & 10 & 8.091 & 18.35 & 16.85 & 0.51 \\
\hline & 20 & 8.161 & 18.43 & 17 & 0.49 \\
\hline & 30 & 8.079 & 18.36 & 16.27 & 0.59 \\
\hline & 40 & 8.213 & 18.31 & 17.27 & 0.54 \\
\hline & 50 & 8.107 & 18.35 & 17.47 & 0.58 \\
\hline & 60 & 8.038 & 18.42 & 16.4 & 0.65 \\
\hline \multirow{7}{*}{ Monsoon } & 0 & 7.954 & 25.21 & 16.5 & 0.5 \\
\hline & 10 & 7.868 & 25.19 & 17.1 & 0.45 \\
\hline & 20 & 7.944 & 25.03 & 16 & 0.42 \\
\hline & 30 & 7.824 & 24.61 & 17.57 & 0.49 \\
\hline & 40 & 7.854 & 24.74 & 16.85 & 0.48 \\
\hline & 50 & 7.764 & 24.75 & 17.17 & 0.47 \\
\hline & 60 & 7.636 & 24.32 & 18.42 & 0.49 \\
\hline \multirow{7}{*}{ Post monsoon } & 0 & 8.288 & 12.92 & 20.75 & 1 \\
\hline & 10 & 8.245 & 12.95 & 21.54 & 0.92 \\
\hline & 20 & 8.323 & 12.91 & 20.78 & 0.93 \\
\hline & 30 & 8.26 & 12.9 & 20.34 & 0.79 \\
\hline & 40 & 8.33 & 12.89 & 21.48 & 0.9 \\
\hline & 50 & 8.305 & 12.88 & 20.51 & 0.83 \\
\hline & 60 & 8.213 & 12.91 & 21.58 & 0.65 \\
\hline
\end{tabular}

Table 4. Multiple regression analysis with a stepwise variable selection $(n=63)^{\star}$.

\begin{tabular}{cccc}
\hline Predictor & $\mathrm{R}^{2}$ & $\mathrm{~F}$ & $\mathrm{P}$ \\
\hline Soil pH & 52.6 & 67.57 & $<0.001$ \\
Soil Temp & 61.9 & 48.77 & $<0.001$ \\
Soil Salinity & 62 & 32.1 & 0.703 \\
Org. C & 74.8 & 43.1 & $<0.001$ \\
Ammonia content & 76.7 & 37.44 & $<0.001$
\end{tabular}

*The dependent variable, soil Urease Activity ( $\mu \mathrm{g} \mathrm{NH}_{4}^{+}-\mathrm{N}$ produced $\mathrm{g}^{-1}$ dry wt of soil) is not shown. Urease Activity $=-236+37.4 \mathrm{pH}-0.900 \mathrm{~T}-0.085 \mathrm{~S}+53.7 \mathrm{Org}$. $\mathrm{C}+5.46$ Ammonia. The independent variables are $\mathrm{pH}, \mathrm{T}\left(\mathrm{Temperature} \mathrm{in}{ }^{\circ} \mathrm{C}\right)$, salinity (S, PSU), Org. $\mathrm{C}(\%)$ and Ammonia ( $\mu \mathrm{g} \cdot \mathrm{g}^{-1}$ dry wt of soil).

region. No distinct stratification was found for soil urease activity and ammonia content because of wave attack and other disturbances in that zone.

\section{References}

[1] Twilley, R.R., Chem, R.H. and Hargis, T. (1992) Carbon Sinks in Mangroves and Their Implications to Carbon Budget to Tropical Coastal Ecosystem. Water, Air \& Soil Pollution, 54, 265-288. https://doi.org/10.1007/BF00477106 
[2] Gattuso, P., Prakignoulle, M. and Wollast, R. (1998) Carbon and Carbonate Metabolism in Coastal Aquatic Ecosystems. Annual Review of Ecology, Evolution, and Systematics, 29, 405-434. https://doi.org/10.1146/annurev.ecolsys.29.1.405

[3] Alongi, D.M. (2009) The Energetics of Mangrove Forest. Springer, Dordrecht, 11-24.

[4] FAO (2004) Status and Trends in Mamgrove Area Extent Worldwide. Forest Resource Assessment Working Paper, 063, 287.

[5] Lovelock, C.E., Feller, I.C., Mc Kee, K.L. and Thompson, R. (2005) Variation in Mangrove Forest Structure and Sediment Characteristics in Bolas del Toro, Panama. Caribbean Journal of Science, 41, 456-464.

[6] Sanders, C.J., Smoak, J.M., Sathy, N.A., Sanders, L.M. and Patchineelam, S.R. (2010) Organic Carbon Burial in a Mangrove Forest, Margin and Intertidal Mud Flat. Estuarine, Coastal and Shelf Science, 90, 168-172.

[7] Sanders, C.J., Smoak, J.M., Waters, M.N., Sanders, L.M., Brandini, N. and Patchineelam, S.R. (2012) Organic Matter Content and Particle Size Modifications in Mangrove Sediments as Responses to Sea Level Rise. Marine Environmental Research, 77, 150-155.

[8] Pinck, L.A. and Allison, F.E. (1961) Adsorption and Release of Urease by and from Clay Minerals. Soil Science, 91, 183-188. https://doi.org/10.1097/00010694-196103000-00008

[9] McLaren, A.D. (1963) Enzyme Activity in Soils Sterilized by Ionising Radiation and Some Comments on Microenvironments in Nature. In: Gibbons, N.E., Ed., Recent Progress in Microbiology, University of Toronto Press, Toronto, Vol. 8, 221-229.

[10] Dinesh, R., Chaudhuri, S.G., Ganeshamurthy, A.N. and Pramanik, S.C. (2004) Biochemical Properties of Soils of Undisturbed and Disturbed Mangrove Forests of South Andaman (India). Wetlands Ecology and Management, 12, 309-320. https://doi.org/10.1007/s11273-004-0777-3

[11] Yang, Q., Tam, N.F.Y., Wong, Y.S., Luan, T.G., Su, W.S., Lan, C.Y., Shin, P.K.S. and Cheung, S.G. (2008) Potential Use of Mangroves as Constructed Wetland for Municipal Sewage Treatment in Futian, Shenzhen, China. Marine Pollution Bulletin, 57, 735-743.

[12] Pettit, N.M., Smith, A.R.J., Freedman, R.B. and Burns, R.G. (1976) Soil Urease: Activity, Stability and Kinetic Properties. Soil Biology and Biochemistry, 8, 479-484.

[13] Klose, S. and Tabatabai, M.A. (1999) Urease Activity of Microbial Biomass in Soils. Soil Biology and Biochemistry, 31, 205-211.

[14] Sinsabaugh, R.L. (1994) Enzymatic Analysis of Microbial Pattern and Process. Biology and Fertility of Soils, 17, 69-74. https://doi.org/10.1007/BF00418675

[15] McCarty, G.W., Shogren, D.R. and Bremner, J.M. (1992) Regulation of Urease Production in Soil by Microbial Assimilation of Nitrogen. Biology and Fertility of Soils, 12, 261-264. https://doi.org/10.1007/BF00336041

[16] Taylor, J.P., Wilson, B., Mills, M.S. and Burns, R.G. (2002) Comparison of Microbial Numbers and Enzymatic Activities in Surface Soils and Subsoils Using Various Techniques. Soil Biology and Biochemistry, 34, 387-401.

[17] Borghetti, C., Gioacchini, P., Marzadori, C. and Gessa, C. (2003) Activity and Stability of Urease-Hydroxyapatite and Urease-Hydroxyapatitehumic Acid Complexes. Biology and Fertility of Soils, 38, 96-101. https://doi.org/10.1007/s00374-003-0628-Z

[18] Andrews, R.K., Blakeley, R.L. and Zerner, B. (1989) Urease: A Ni (II) Metalloenzyme. In: Lancaster, J.R., Ed., The Bioinorganic Chemistry of Nickel, VCH, New York, 141-166. 
[19] Byrnes, B.H. and Amberger, A. (1989) Fate of Broadcast Urea in a Flooded Soil When Treated with N-(nbutyl) Thiophospheric Triamide, a Urease Inhibitor. Fertility Research, 18, 221-231. https://doi.org/10.1007/BF01049572

[20] Simpson, J.R. and Freney, J.R. (1988) Interacting Processes in Gaseous Nitrogen Loss from Urea Applied to Flooded Rice Fields. In: Pushparajah, E., Husin, A., Bachik, A.T., Eds., Proceedings of International Symposium on Urea Technology and Utilization, Malaysian Society of Soil Science, Kuala Lumpur, 281-290.

[21] Simpson, J.R., Freney, J.R., Wetselaar, R., Muirhead, W.A., Leuning, R. and Denmead, O.T. (1984) Transformations and Losses of Urea Nitrogen after Application to Flooded Rice. Australian Journal of Agricultural Research, 35, 189-200. https://doi.org/10.1071/AR9840189

[22] Rotini, O.T. (1935) La trasformazione enzimatica dell'urea nel terreno. Ann Labor Ric Ferm Spallanrani, 3, 143-154.

[23] Polacco, J.C. (1977) Is Nickel a Universal Component of Plant Ureases? Plant Science Letters Journal, 10, 249-255.

[24] Burns, R.G. (1986) Interaction of Enzymes with Soil Mineral and Organic Colloids. In: Huang, P.M. and Schnitzer, M., Eds., Interactions of Soil Minerals with Natural Organics and Microbes, Soil Science Society of America, Madison, 429-452.

[25] Mobley, H.L.T. and Hausinger, R.P. (1989) Microbial Urease: Significance, Regulation and Molecular Characterization. Microbiological Reviews, 53, 85-108.

[26] Zantua, M.I. and Bremner, J.M. (1977) Stability of Urease in Soils. Soil Biology and Biochemistry, 9, 135-140.

[27] Tabatabai, M.A. (1977) Effect of Trace Elements on Urease Activity in Soils. Soil Biology and Biochemistry, 9, 9-13.

[28] Yang, Z., Liu, S., Zheng, D. and Feng, S. (2006) Effects of Cadmium, Zinc and Lead on Soil Enzyme Activities. Journal of Environmental Sciences, 18, 1135-1141.

[29] Trasar-Cepeda, C., Gil-Sotres, F. and Leiros, M.C. (2007) Thermodynamic Parameters of Enzymes in Grassland Soils from Galicia, NW Spain. Soil Biology and Biochemistry, 39, 311-319.

[30] Grasshoff, E. and Kremling (1983) Standard Method for Sea Water Analysis. 2nd Edition.

[31] Walkey, J.A. and Black, J.A. (1934) Estimation of Organic Carbon by the Chromic Acid Titration Method. Soil Science, 37, 29-31.

[32] Richards, L.A. (1968) Diagnosis and Improvement of Saline and Alkali Soils. USDA Agriculture Hand Book No. 60. Oxford and IBH Publishing Co., New Delhi.

[33] Subhajit, D., Minati, D., Raghab, R., Chumki, C., Tapan, K.J. and Tarun, K.D. (2011) Microbial Ecosystem in Sunderban Mangrove Forest Sediment, North-East Coast of Bay of Bengal, India. Geomicrobiology Journal, 29, 656-666. https://doi.org/10.1080/01490451.2011.605988

[34] Tiwari, S.C., Tiwari, B.K. and Mishra, R.R. (1989) Microbial Community, Enzyme Activity and $\mathrm{CO}_{2}$ Evolution in Pineapple Orchard Soil. Journal of Tropical Ecology, 30, 265-273.

[35] Ellen, K. and Gerber, H. (1988) Short-Term Assay of Soil Urease Activity Using Colorimetric Determination of Ammonium. Biology and Fertility of Soils, 6, $68-72$.

[36] Paolini, J.E. and Sánchez-Arias, L.E. (2008) Comparative Biochemical Study of the 
Rhizosphere of Rhizophoramangle and Its Associated Species Cyperus sp. in the Ciénaga deSoledad (Colombia) In: Lieth, H., et al., Eds., Mangroves and Halophytes. Restoration and Utilisation, Springer Science + Business Media B.V., Berlin, 79-84.

[37] Zhou, X., Zhang, Y. and Downing, A. (2011) Non-Linear Response of Microbial Activity across a Gradient of Nitrogen Addition to a Soil from the Gurbantunggut Desert, Northwestern China. Soil Biology and Biochemistry, 30, 1-11.

[38] Pett-Ridge, J., Petersen, D.G., Nuccio, E. and Firestone, M.K. (2013) Influence of Oxic/Anoxic Fluctuations on Ammonia Oxidizers and Nitrification Potential in a Wet Tropical Soil. FEMS Microbiology Ecology, 85, 179-194. https://doi.org/10.1111/1574-6941.12111

[39] Das, S., Sarkar, T.K., De, M., Ganguly, D., Maiti, T.K., Mukherjee, A., Jana, T.K. and De, T.K. (2011) Depth Profile Exploration of Enzyme Activity and Culturable Microbial Community from the Oxygen-Starved Soil of Sundarban Mangrove Forest, India. Open Journal of Ecology, 1, 65-72.

[40] Das, S., Ganguly, D., Maiti, T.K., Mukherjee, A., Jana, T.K. and De, T.K. (2013) A Depth Wise Diversity of Free Living $\mathrm{N}_{2}$ Fixing and Nitrifying Bacteria and Its Seasonal Variation with Nitrogen Containing Nutrients in the Mangrove Sediments of Sundarban, WB, India. Open Journal of Marine Science, 3, 112-120.

[41] Agehara, S. and Warncke, D.D. (2005) Soil Moisture and Temperature Effects on Nitrogen Release from Organic Nitrogen Sources. Soil Science Society of America Journal, 69, 1844-1855. https://doi.org/10.2136/sssaj2004.0361

\section{Submit or recommend next manuscript to SCIRP and we will provide best service for you:}

Accepting pre-submission inquiries through Email, Facebook, LinkedIn, Twitter, etc. A wide selection of journals (inclusive of 9 subjects, more than 200 journals) Providing 24-hour high-quality service User-friendly online submission system Fair and swift peer-review system Efficient typesetting and proofreading procedure Display of the result of downloads and visits, as well as the number of cited articles Maximum dissemination of your research work

Submit your manuscript at: http://papersubmission.scirp.org/

Or contact aim@scirp.org 